\title{
Serious Games in the Classroom: Student Learning Outcomes
}

\author{
Loubna EL AZIZI \\ Department of mathematics. Laboratory: Algebra and Operator Theory, Faculty of Sciences, \\ Abdelmalek Essaadi University, Tetouan, Morocco
}

\begin{abstract}
The objective of the study presented in this paper, is to determine the potential effects that serious games can have on the learning of primary school students. This study concentrated on learning mathematics especially mental calculation, a subject that is often regarded as complicated by students of all ages in schools. An experiment was carried out to investigate how the serious games affect arithmetic learning. Two groups were assigned, a control and experimental group. Controlled students have learned mental calculation by traditional teaching method and the experimental group used our Serious Games. A t-test using SPSS statistical software was carried out to test the existence of significant change in students' performance based on the marks they scored on a test for a mental calculation before and after the introduction of serious games in students learning process.. Based on the analysis carried out, results show that the students in the experimental group performed better when using serious games than the control group with traditional teaching method. And those serious games positively influence the motivation of learners.
\end{abstract}

Keywords: Serious Games, Mental calculation, Primary school, Mathematics, Motivation.

\section{INTRODUCTION}

At a time when the question of educational innovation is more present in the debates, a growing interest is more focused on Serious Games and their uses as learning tools for the teaching. A Serious Game is a computer application that combines both fun and serious aspects whose primary purpose is other than just entertainment. Currently, these devices offer dimensions of immersion, development of skills and emotions as during a mission in a real context. These advantages allow the learner to live a real situation in a virtual context and thus retain more knowledge on the subject. Thus his motivation will be increased, compared to conventional modes of teaching. There are many studies showing the benefits of computer games for children and adults in terms of providing motivation, engagement, developing skills and encouraging collaboration. Wood and Stewart(1987) asserted that incorporating digital games into instructional design improves students' skills in practical reasoning, complex problem solving (Hayes,1981) transfer of learning (Crisafulli \&Antonietti,1993)making inferences and engaging in inductive reasoning (Mayer \&Sims,1994)and using Metaphorical Maps to generate alternative solution paths(Quinn,1996).Other researchers that explored this area includes Prensky (2001), who discussed the potential of educational computer games and listed twelve elements as to why games engage people. Those reasons includes: games motivate players (to achieve goals), gratify the ego (when winning), are fun (through enjoyment and pleasure) and spark the players' creativity (to solve the game problem). The use of interactive games has impacted the mode of learning. (Foreman et al., 2004). Krasilovsky (1996) claimed that young learners tend to 'favor "edutainment" applications-academics-oriented games.' Wood (2001) investigated the use of learning games as a learning tool and concluded that game-like formats could be more effective at capturing learners' attention than traditional media such as textbooks. Looking at all these claims on the potential of game based learning, there is need to reconceptualise our attitude and thinking on how the Moroccan digital natives will maximize the potential benefits of computer games to motivate and engage the primary schools students in mental calculation . Also, this research hopes to address the problem of boredom, and lack of interest which pupils always complain when learning Mathematics.

The desire to harness this motivational power to encourage students to want to learn is the main drive behind an interest in serious games for learning. The objective of this study, is to find out how well Serious games can motivate and engage the Moroccan pupils to learn mathematics efficiently and to identify the necessary factors that may hinder the students motivation in learning with serious games as it supplements the traditional teaching. And to determinate the impacts of these serious games on students learning.

\section{II.PURPOSE OF THE STUDY}

This study was conducted in fifth and sixth grade of primary school in Morocco. Our Serious Games have been designed to develop mental math skills among students. We wanted to enrich the traditional learning of this subject by the use of these serious games and study the contribution of these on the learning of students. To do this, we propose an 


\author{
Vol. 8, Issue 12, December 2019
}

evaluation grid and the students have passed two tests (Pretest and Posttest). From these variables, serious games will be evaluated to measure the performance and impact of this tool on student learning.

\title{
III.RESEARCH QUESTIONS
}

This paper present feedback on the use of serious games developed for learning mathematics, specifically mental calculation. The central research questions that this study aimed to answer are:

- $\quad$ Do the serious games lead to better mental calculation learning than the traditional method?

- $\quad$ Are they efficient in developing learners' learning?

Our hypotheses are:

- $\quad$ The learning level of Experimental group will be greater than the learning level of control group for addition, subtraction, multiplication and division.

- $\quad$ The control group will make more error than experimental group.

- $\quad$ The experimental group will enjoy more than the control group.

\section{IV.RESEARCH METHOD AND DESIGN}

\subsection{Population and sampling}

The original set of participants were $54,5^{\text {th }}$ and $6^{\text {th }}$ grade primary school students from private school in Morocco. Fifty five (54) participants are divided into two groups (control group $(n=27)$, experimental group $(n=27)$ ). The two groups were not randomly assigned to the Game and Non-Game groups. Instead, they were assigned to balance low performing and high performing students between the experimental and Control group.

A pretest and posttest was administered to both groups. The experimental group underwent an intervention where they learnt mental calculation using our Serious Games for eight weeks, while the control group learnt mental calculation using traditional method.

After a pretest we divided the students into two groups: Control and Experimental group.

Fig1: Composition of groups

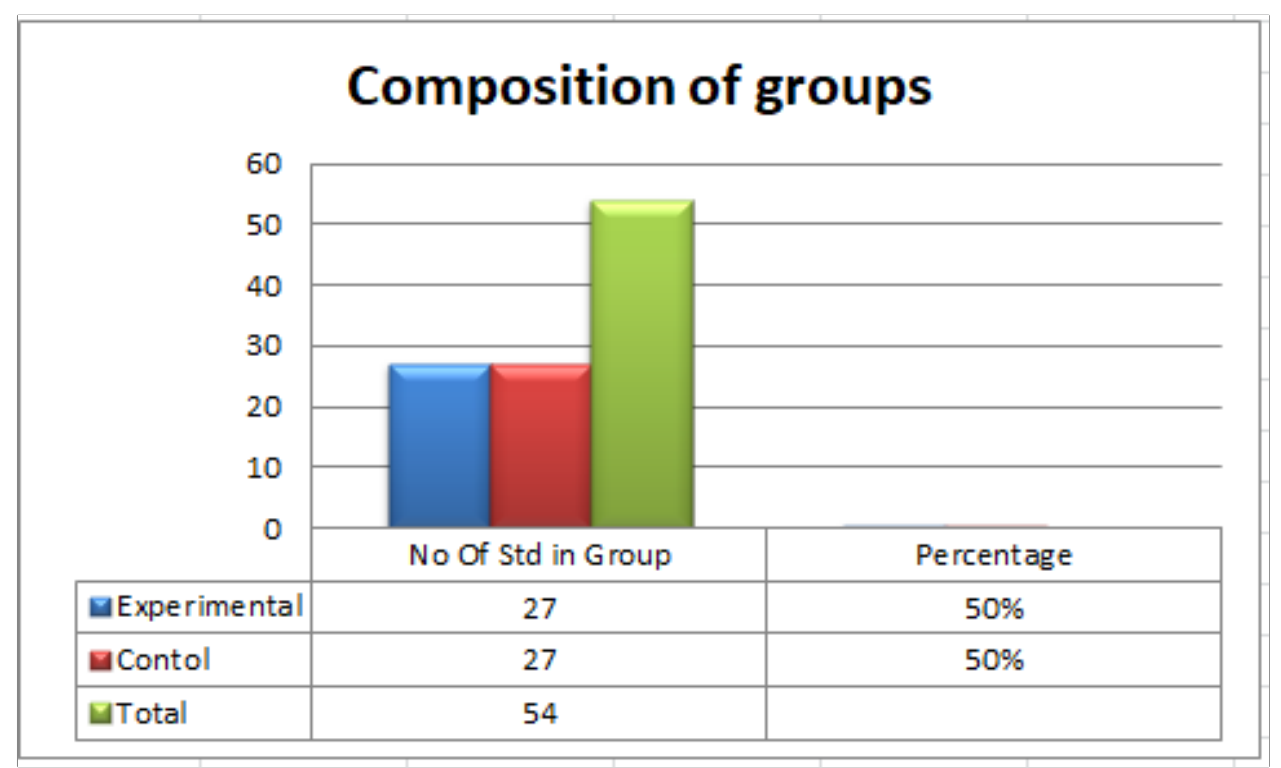

\subsection{Our serious games}

The serious games were designed and developed to train primary school students and improve their mental calculation skills. We wanted to enrich the traditional learning of this subject with the use of these serious games, and to study the contributions of these on the development of the learning of the students. These games are single-player in which the learner-player can learn, understand and apply his skills. 


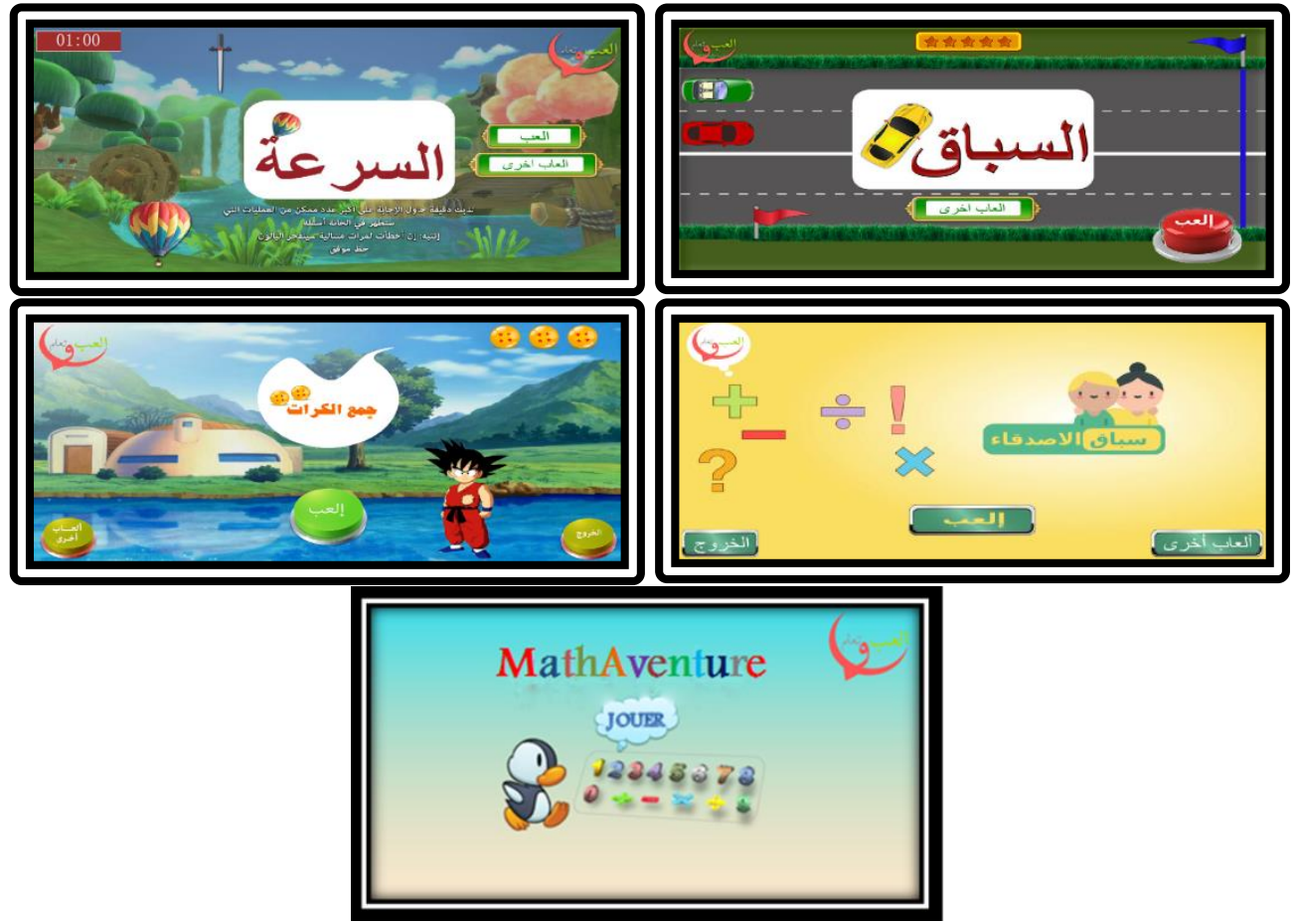

\subsection{Materials}

In order to evaluate the potential effects that serious games can have on the learning of primary school students in mental calculation, we compared two cases: a group of participants used the traditional method to acquire the mental calculation skills; another group of participants used our Serious Games previously described. The first group is called the control group and the second group is called the experimental group. Each group consisted of 27 participants recruited from fifth and sixth grade of primary school students.

We want to make it clear now that we did not consider gender in our study given the small size of the samples. A larger study would be needed to draw conclusions at this level. All participants of both conditions had not used serious games. A one-hour training was therefore conducted a week before the experimental session to give them the basic knowledge necessary for the use of our serious games.

For each group, the experimental session was conducted in 54 hours with three distinct stages: 1) Short presentation of the research project and pretest to assess the state of knowledge of the participants on mental calculation; 2) the actual game session and 3) a posttest to assess the state of knowledge after the use of serious games.

As previously mentioned, the evaluation of the experiment was conducted using a questionnaire and two tests. They called the pretest and posttest, the first was used before the game session and then immediately afterwards we use the posttest to measure the evolution of knowledge. It has been designed to respond to research hypotheses.

The beginning of the questionnaire concerns some general information about the participant. It was organized around three groups of items: "evaluation framework of learning with serious games": playability, learning, reality. It was used to measure the user experience, the usability of serious games and the perception of participants about their learning.

The data used for this research are based on Lickert scales from 1 to $10(0=$ disagree at all; $1=$ rather disagree; $2=$ rather agree, 3 = completely agree) and the closed questions.

It was important to guide the participants in their practice of the serious games without biasing the information necessary for the study conducted: a very good knowledge of the serious game, the instructions of them was mandatory to help students with some difficulties to complete the games. At the end of the test, each student completed the questionnaire of each serious game. I observed students and I assisted them in case of difficulties.

\section{V.RESULTS}

Statistical Package for the Social Sciences (SPSS) was used to answer the objectives of this study. Achievement test scores were analyzed. The test was used to test for the Mean score, Students' knowledge of the addition, subtraction, multiplication and division between the pretest and posttest exam for the control group and experimental group. And SPSS was used to test the independent t-test for pretest and posttest for both groups. 


\subsection{User experience rating with serious games:}

Table1: Participants' thoughts on the overall design of serious games

\begin{tabular}{|c|c|c|cc|}
\hline I think that serious games are: & Mean & Deviation & Max & Min \\
\hline Useful & 2,92 & 0,27 & 3,0 & 2,0 \\
\hline Relevant & 2,63 & 0,49 & 3,0 & 2,0 \\
\hline Amasing & 2,37 & 0,68 & 3,0 & 1,0 \\
\hline Easy to use & 2,48 & 0,64 & 3,0 & 1,0 \\
\hline
\end{tabular}

As mentioned above, the user experience was evaluated from a questionnaire that was offered to students after the use of serious games. It consisted of closed questions with answers on a four-tierscale scale $(0=$ disagree at all; $1=$ rather disagree; 2 = rather agree, 3 = completely agree), or in the form of multiple-choice questions. Table 1 shows that students who have used serious games have rather positive opinions about usefulness, relevance, playfulness and ease of use (with mean scores of 2.92- 2.63- 2.37 and 2.48). The students' point of view is relatively homogeneous.

Figure 2: Emotions felt by the participants

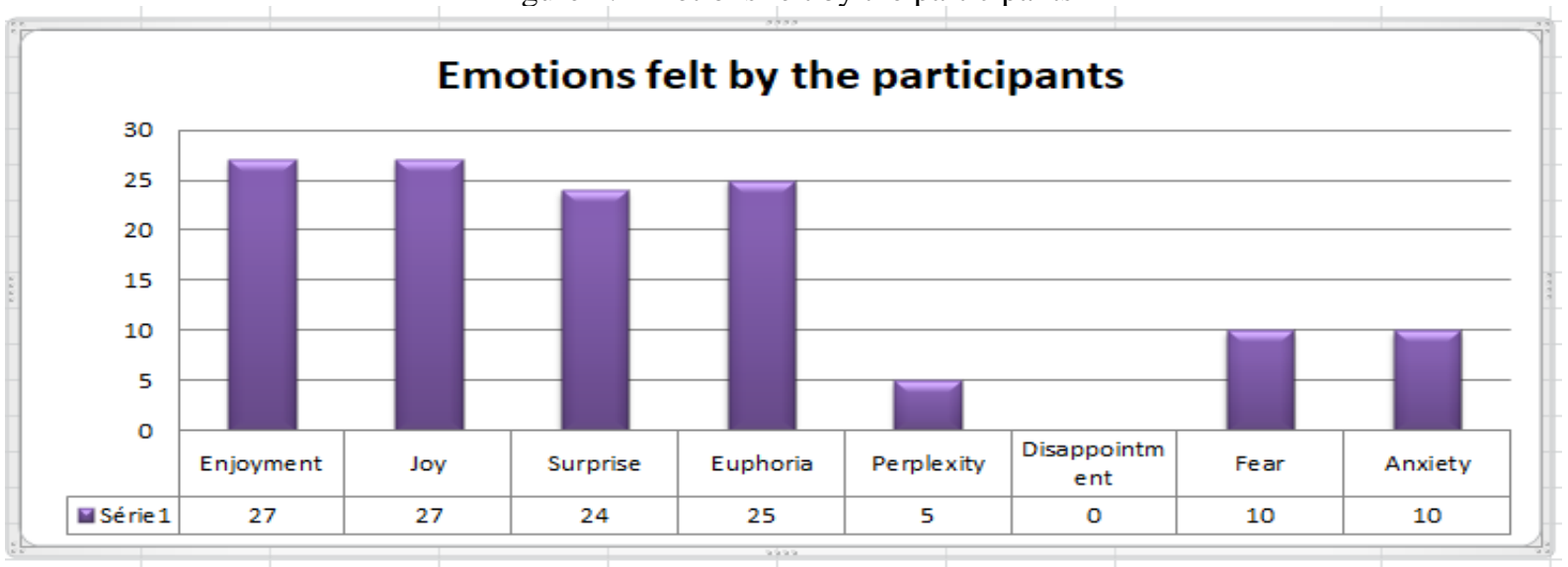

We then asked the participants the level of feeling of different emotions when using Serious Games. Table 2 shows the answers given. The emotions most often expressed are positive like pleasure (27 learners) and joy (27). Some students expressed a feeling of surprise (24) or euphoria (25). Most students did not express negative emotions. Some students expressed a feeling of stress at the idea of making miscalculations or failing to win in the serious game (10).

\subsection{Assessment of learning}

\subsubsection{Feeling of learning}

Participants' feelings of learning are presented in Table 2. They feel they have the ability to calculate additions $(\mathrm{m}=$ 2.59 for the control group vs $\mathrm{m}=2.48$ for the experimental group), calculate the subtractions $(\mathrm{m}=1.74$ for the control group vs $\mathrm{m}=1.62$ for the experimental group), calculate the multiplications $(\mathrm{m}=2.07$ for the control group vs $\mathrm{m}=$ 1.92 for the experimental group), and calculate the divisions ( $\mathrm{m}=1.62$ for the control group vs $\mathrm{m}=1.48$ for the experimental group). The Values are very similar in both groups.

It can therefore be concluded that the perception of learning is similar in both groups.

Table 2 : Participants' Learning feelings

\begin{tabular}{|c|c|c|c|c|c|}
\hline & & Mean & Deviation & $\operatorname{Max}$ & Min \\
\hline \multirow{4}{*}{ Control group } & $\begin{array}{l}\text { I am able to } \\
\text { calculate the } \\
\text { additions }\end{array}$ & 2,59 & 0,5 & 3 & 1 \\
\hline & $\begin{array}{l}\text { I am able to } \\
\text { calculate the } \\
\text { subtractions }\end{array}$ & 1,74 & 0,52 & 3 & 1 \\
\hline & $\begin{array}{l}\text { I am able to } \\
\text { calculate } \\
\text { multiplications }\end{array}$ & 2,07 & 0,67 & 3 & 1 \\
\hline & $\begin{array}{l}\text { I am able to } \\
\text { calculate }\end{array}$ & 1,62 & 0,68 & 3 & 1 \\
\hline
\end{tabular}


Vol. 8, Issue 12, December 2019

\begin{tabular}{|c|c|c|c|c|c|}
\hline & divisions & & & & \\
\hline \multirow{4}{*}{$\begin{array}{l}\text { Experimental } \\
\text { group }\end{array}$} & $\begin{array}{l}\text { I am able to } \\
\text { calculate the } \\
\text { additions }\end{array}$ & 2,48 & 0,5 & 3 & 1 \\
\hline & $\begin{array}{l}\text { I am able to } \\
\text { calculate the } \\
\text { subtractions }\end{array}$ & 1,62 & 0,56 & 3 & 1 \\
\hline & $\begin{array}{l}\text { I am able to } \\
\text { calculate } \\
\text { multiplications }\end{array}$ & 1,92 & 0,72 & 3 & 1 \\
\hline & $\begin{array}{l}\text { I am able to } \\
\text { calculate } \\
\text { divisions }\end{array}$ & 1,48 & 0,64 & 3 & 1 \\
\hline
\end{tabular}

\subsubsection{Level of knowledge of participants before training:}

Table 3: Pretest Results for the both groups

\begin{tabular}{|cllccc|}
\hline Pretest & & Mean & Deviation & Max & Min \\
\hline \multirow{3}{*}{ Control group } & Addition & 6,63 & 1,54 & 10 & 5 \\
\cline { 2 - 6 } & Subtraction & 5,92 & 1,49 & 8 & 4 \\
\cline { 2 - 6 } & Multiplication & 6,33 & 1,66 & 10 & 4 \\
\cline { 2 - 6 } experimental & Division & 5,74 & 1,22 & 8 & 4 \\
\cline { 2 - 6 } group & Addition & 6,55 & 1,47 & 10 & 4 \\
\cline { 2 - 6 } & Subtraction & 5,85 & 1,43 & 10 & 4 \\
\cline { 2 - 6 } & Multiplication & 6,11 & 1,62 & 8 & 3 \\
\hline
\end{tabular}

Figure 3: Pretest results for the two groups

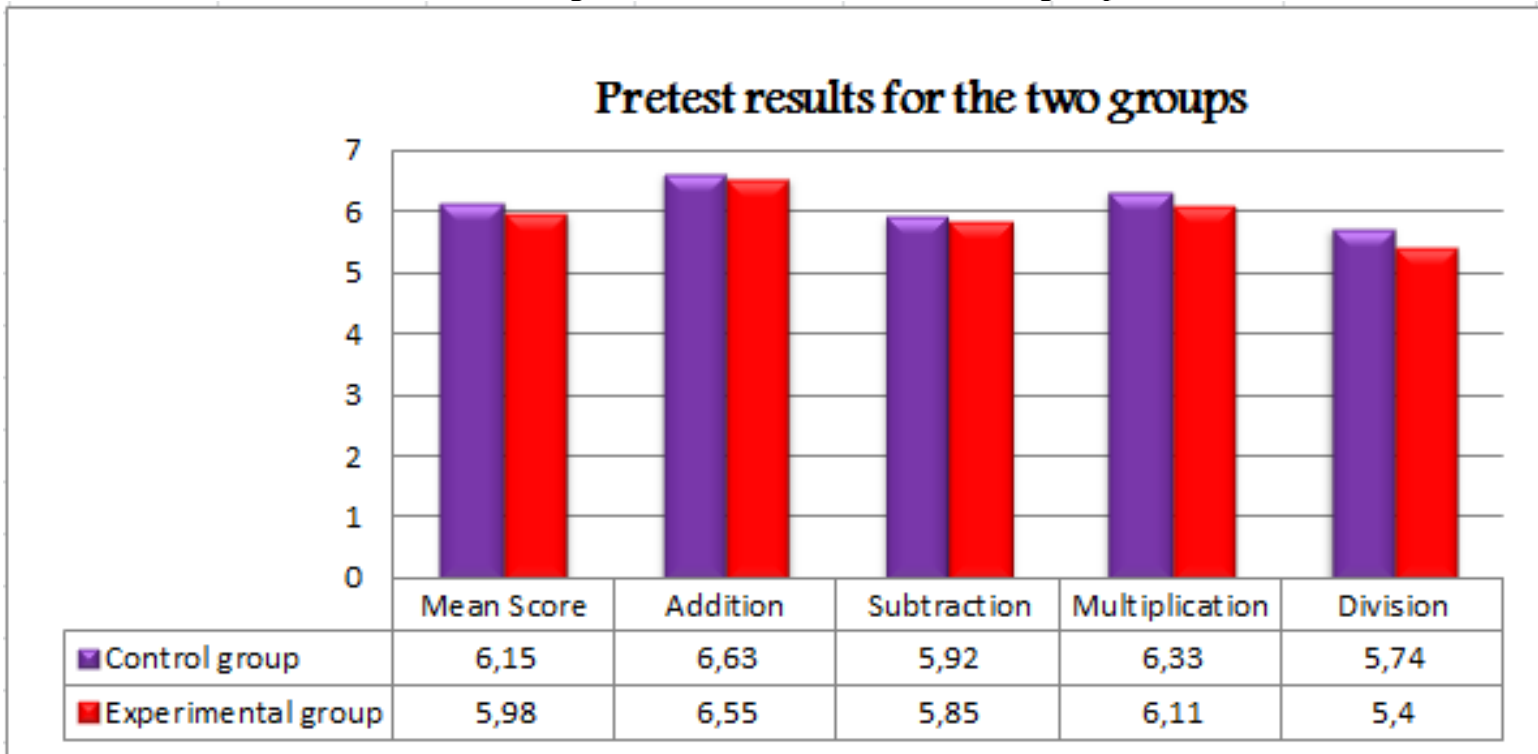

The table 3 and figure 3 show level knowledge of student', prior to training of addition, subtraction, multiplication and division. After the pretest, we divided the learners into two groups according to their initial knowledge. Control group (27 students) and the experimental group (27 students). 
International Journal of Advanced Research in Computer and Communication Engineering

Vol. 8, Issue 12, December 2019

Addition

Table 4: Result of the Independent t-test on the pretest of both groups

\begin{tabular}{|c|c|c|c|c|c|}
\hline Group & $\mathbf{N}$ & Mean & $\begin{array}{c}\text { Std. } \\
\text { Deviation }\end{array}$ & T & Sig.(2 Tailed) \\
\hline Experimental & 27 & 6,56 & 1,48 & $-0,18$ & 0,86 \\
\hline Control & 27 & 6,63 & 1,55 & & \\
\hline
\end{tabular}

Subtraction

\begin{tabular}{|c|c|c|c|c|c|}
\hline Group & N & Mean & $\begin{array}{c}\text { Std. } \\
\text { Deviation }\end{array}$ & T & Sig.(2 Tailed) \\
\hline Experimental & 27 & 5,85 & 1,43 & $-0,19$ & 0,85 \\
\hline Control & 27 & 5,93 & 1,5 & & \\
\hline
\end{tabular}

Multiplication

\begin{tabular}{|c|c|c|c|c|c|}
\hline Group & N & Mean & $\begin{array}{c}\text { Std. } \\
\text { Deviation }\end{array}$ & T & Sig.(2 Tailed) \\
\hline Experimental & 27 & 6,11 & 1,63 & $-0,5$ & 0,62 \\
\hline Control & 27 & 6,33 & 1,66 & & \\
\hline
\end{tabular}

Division

\begin{tabular}{|c|c|c|c|c|c|}
\hline Group & N & Mean & $\begin{array}{c}\text { Std. } \\
\text { Deviation }\end{array}$ & T & Sig.(2 Tailed) \\
\hline Experimental & 27 & 5,41 & 1,15 & $-1,03$ & 0,31 \\
\hline Control & 27 & 5,74 & 1,29 & & \\
\hline
\end{tabular}

Total Knowledge

\begin{tabular}{|c|c|c|c|c|c|}
\hline Group & $\mathbf{N}$ & Mean & $\begin{array}{c}\text { Std. } \\
\text { Deviation }\end{array}$ & T & Sig.(2 Tailed) \\
\hline Experimental & 27 & 5,98 & 0,58 & $-1,16$ & 0,25 \\
\hline Control & 27 & 6,18 & 0,55 & & \\
\hline
\end{tabular}

We analyzed whether the differences between the two groups were significant using a t-test. The results presented in Table 4 show that there is no significant difference in the state of initial knowledge between the two groups for addition $(p=0.86)$, subtraction $(p=0.85)$, multiplication $(p=0.62)$ and division $(p=0.31)$. And also for the total knowledge with $(\mathrm{p}=0,25)$. We can therefore conclude that the initial level of knowledge of the participants is equivalent before the experiment for the two groups.

\subsubsection{Level of knowledge of participants after training:}

After the experiment, the students passed a posttest exam to determine if there is any development in the learning or not.

Figure 4: Pretest and Posttest Results for the control group

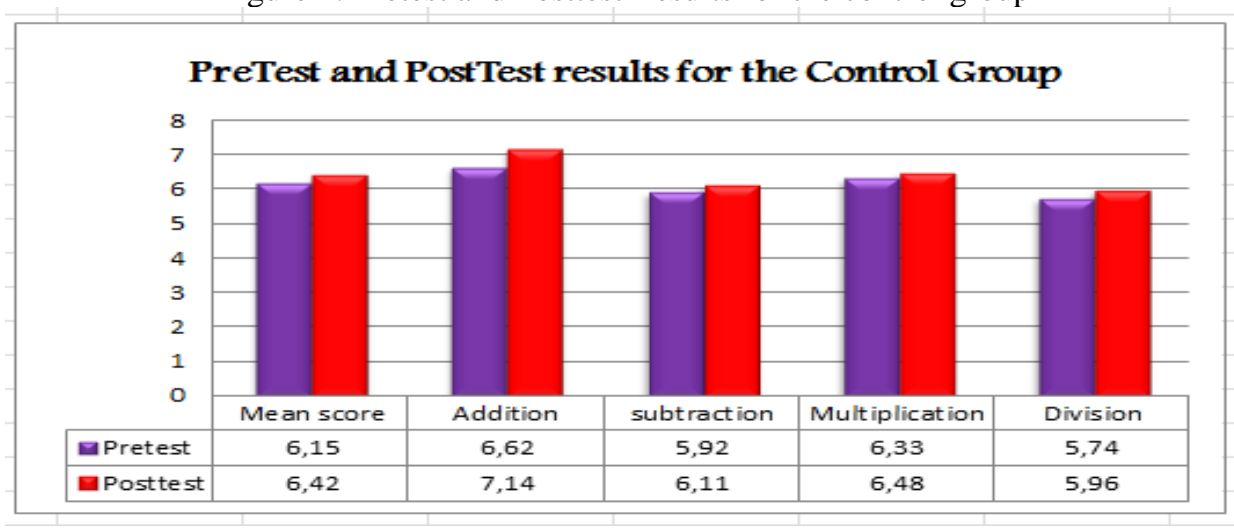


Vol. 8, Issue 12, December 2019

The Figure 4 showed that the control group obtained a mean score of 6.15 in pretest exam while they obtained 6.42 in posttest exam. The students addition skill in pretest was 6,62, while in posttest was 7,14, the students subtractions skill in pretest was 5,92, while in posttest was 6,11 , the multiplication skill in pretest was 5,74, while in posttest was 5,92 Finally, the students had 5,74 in division skill in pretest and 5,96 in posttest. This means that there has been an improvement in mental calculation skills after the training.

Figure 5: Pretest and Posttest Results for the experimental group

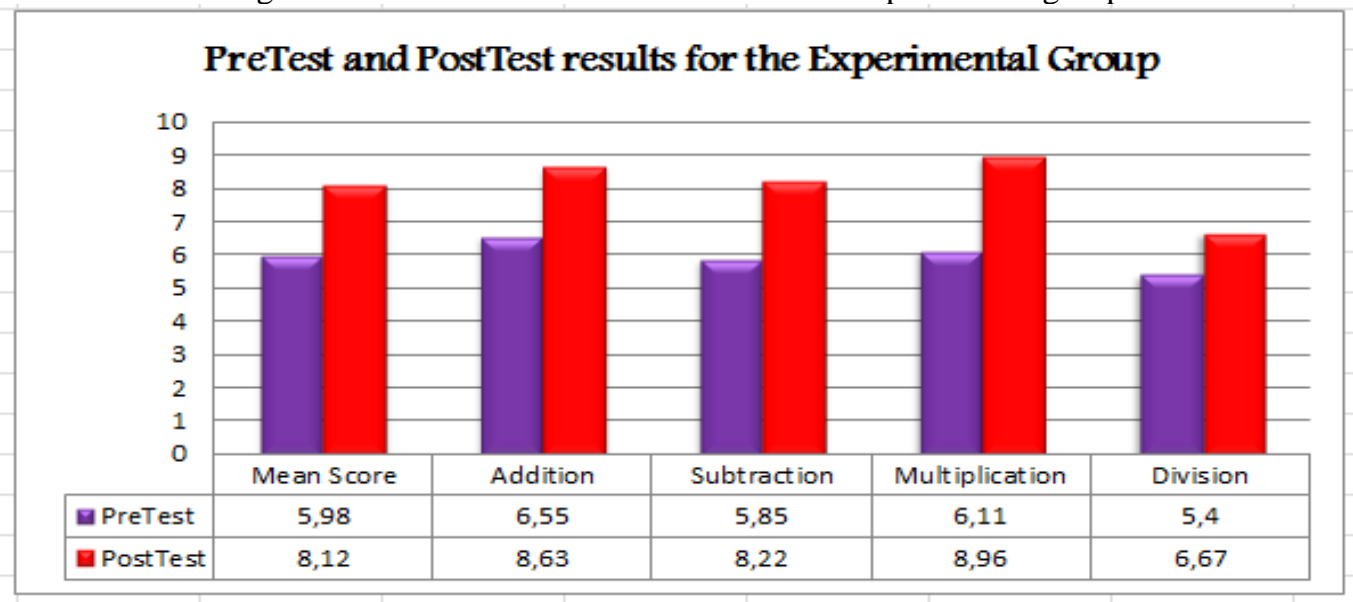

The Figure 5 showed that the experimental group obtained a mean score of 5,98 in pretest exam while they obtained 8,12 in posttest exam. The students addition skill in pretest was 6,55 while in posttest was 8,62 , the students subtraction skill in pretest was 5,85 while in posttest was 8,22 , the multiplication skill in pretest was 6,11 , while in posttest was 8,96 Finally, the students had 5,4 in division skill in pretest and 6,66 in posttest. This means that there has been an improvement in mental calculation skills after training.

So, the two groups had an improvement in mental calculation learning after training.

Table 6: Posttest Results for the two groups

\begin{tabular}{|lllccc|}
\hline Posttest & & Mean & Deviation & Max & Min \\
\hline \multirow{3}{*}{ Control Group } & Addition & $\mathbf{7 , 1 4}$ & $\mathbf{1 , 4 1}$ & $\mathbf{1 0}$ & $\mathbf{5}$ \\
\cline { 2 - 6 } & Subtraction & $\mathbf{6 , 1 1}$ & $\mathbf{1 , 4 0}$ & $\mathbf{1 0}$ & $\mathbf{5}$ \\
\cline { 2 - 6 } & Multiplication & $\mathbf{6 , 4 8}$ & $\mathbf{1 , 5 5}$ & $\mathbf{1 0}$ & $\mathbf{4}$ \\
\cline { 2 - 6 } Experimental & Division & $\mathbf{5 , 9 6}$ & $\mathbf{1 , 0 6}$ & $\mathbf{8}$ & $\mathbf{3}$ \\
\cline { 2 - 6 } Group & Addition & $\mathbf{8 , 6 3}$ & $\mathbf{1 , 0 8}$ & $\mathbf{1 0}$ & $\mathbf{7}$ \\
\cline { 2 - 6 } & Subtraction & $\mathbf{8 , 2 2}$ & $\mathbf{1 , 5 3}$ & $\mathbf{1 0}$ & $\mathbf{7}$ \\
\cline { 2 - 6 } & Multiplication & $\mathbf{8 , 9 6}$ & $\mathbf{0 , 9 4}$ & $\mathbf{1 0}$ & $\mathbf{7}$ \\
\cline { 2 - 6 } & Division & $\mathbf{6 , 6 7}$ & & & $\mathbf{1 0}$ \\
\hline
\end{tabular}

Figure 6: Posttest Results for the two groups

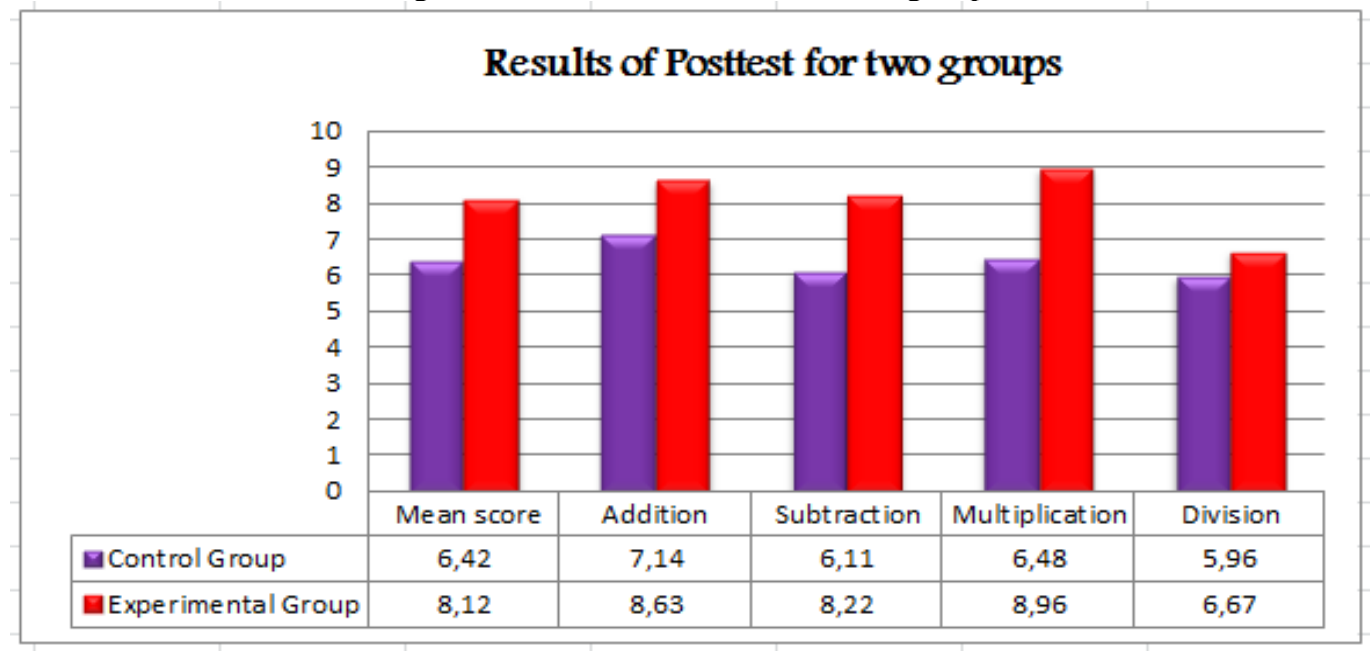


Vol. 8, Issue 12, December 2019

The figure 6 showed ' level knowledge of students after training. We can see that the experimental group has better results on the skill set than the control group $(\mathrm{m}=6.42$ for the control group vs $\mathrm{m}=8.12$ for the experimental group). The experimental group has in particular better results regarding subtraction $(\mathrm{m}=6,11$ for the control group vs $\mathrm{m}=$ 8,22 for the experimental group). The results are also better for multiplication $(\mathrm{m}=6.48$ for the control group v $\mathrm{m}=$ 8.96 for the experimental group). The results are also better for the addition but much less marked ( $\mathrm{m}=7.14$ for the control group vs $\mathrm{m}=8.63$ for the experimental group). The two groups didn't better score in division skill ( $\mathrm{m}=5.96$ for the control group vs $\mathrm{m}=6.67$ for the experimental group).

Addition:

Tables 7: Results of the Independent t-test on the Posttest of two groups

\begin{tabular}{|c|c|c|c|c|c|}
\hline Group & N & Mean & $\begin{array}{c}\text { Std. } \\
\text { Deviation }\end{array}$ & T & Sig. (2 Tailed) \\
\hline Experimental & 27 & 8,63 & 1,08 & 4,343 & 0,000065 \\
\hline Control & 27 & 7,15 & 1,41 & \\
\hline
\end{tabular}

\section{Subtraction:}

\begin{tabular}{|c|c|c|c|c|c|}
\hline Group & N & Mean & $\begin{array}{c}\text { Std. } \\
\text { Deviation }\end{array}$ & T & Sig. (2 Tailed) \\
\hline Experimental & 27 & 8,22 & 1,53 & 5,301 & 0,000002 \\
\hline Control & 27 & 6,11 & 1,4 & & \\
\hline
\end{tabular}

\section{Multiplication:}

\begin{tabular}{|c|c|c|c|c|c|}
\hline Group & N & Mean & $\begin{array}{c}\text { Std. } \\
\text { Deviation }\end{array}$ & T & Sig. (2 Tailed) \\
\hline Experimental & 27 & 8,96 & 0,94 & 7,102 & $3,4028 \mathrm{E}-9$ \\
\hline Control & 27 & 6,48 & 1,55 & \\
\hline
\end{tabular}

Division:

\begin{tabular}{|c|c|c|c|c|c|}
\hline Group & N & Mean & $\begin{array}{c}\text { Std. } \\
\text { Deviation }\end{array}$ & T & Sig. (2 Tailed) \\
\hline Experimental & 27 & 6,67 & 1,3 & 2,183 & 0,033592 \\
\hline Control & 27 & 5,96 & 1,05 & \\
\hline
\end{tabular}

Total knowledge:

\begin{tabular}{|c|c|c|c|c|c|}
\hline Group & N & Mean & $\begin{array}{c}\text { Std. } \\
\text { Deviation }\end{array}$ & T & Sig. (2 Tailed) \\
\hline Experimental & 27 & 8,12 & 0,53 & 12,208 & $6,8329 \mathrm{E}-17$ \\
\hline Control & 27 & 6,43 & 0,49 & \\
\hline
\end{tabular}

This independent sample t-test was done to examine whether any significant differences exist between the posttest mean score of both the Control and Experimental group.

Do the serious game lead to better mental calculation learning than the traditional method?

Are they efficient in developing learners' learning?

Using SPSS to assess the posttest, with the pretest, the Experimental group performed significantly better than the Control group on the posttest. The addition learning of Experimental group $(M=8,63, S D=1,08$, $n=27)$ was hypothesized to be greater than learning level in addition of control group $(\mathrm{M}=7,15, \mathrm{SD}=1,41, \mathrm{n}=27)$. This different was significant $\mathrm{t}(54)=4,343, \mathrm{p}=3,26851 \mathrm{E}-05$. The subtraction learning $\mathrm{t}$ of Experimental group $(\mathrm{M}=8,22, \mathrm{SD}=1,53$, $\mathrm{n}=27$ ) was hypothesized to be greater than learning level in subtraction of control group $(\mathrm{M}=6,11, \mathrm{SD}=1,4, \mathrm{n}=27)$. This different was significant $\mathrm{t}(54)=5,301, \mathrm{p}=0,000002$. The Multiplication learning of Experimental group ( $\mathrm{M}=8,96$, $\mathrm{SD}=0,94, \mathrm{n}=27$ ) was hypothesized to be greater than learning level in Multiplication of control group (M=6,48, $\mathrm{SD}=1,55, \mathrm{n}=27)$. This different was significant $\mathrm{t}(54)=7,102, \mathrm{p}=3,4028 \mathrm{E}-9$. The Division learning of Experimental group $(M=6,67, S D=1,3, n=27)$ was hypothesized to be greater than learning level in Division of control group 


\title{
International Journal of Advanced Research in Computer and Communication Engineering
}

\author{
Vol. 8, Issue 12, December 2019
}

$(\mathrm{M}=5,96, \mathrm{SD}=1,05, \mathrm{n}=27)$. This different was significant $\mathrm{t}(54)=2,183, \mathrm{p}=0,033592$. The total knowledge learning of Experimental group $(\mathrm{M}=8,12, \mathrm{SD}=0,53, \mathrm{n}=27)$ was hypothesized to be greater than learning level in total knowledge of control group $(M=6,43, S D=0,49, n=27)$. This different was significant $t(54)=12,208$,

$\mathrm{p}=6,8329 \mathrm{E}-17$.

Findings from this study showed that the experimental group improvement is higher than the control group. The superiority of the Experimental group on test of learning is the main finding in this study. So we can conclude that using the serious games in classes is more efficient than the traditional method.

\section{VI.DISCUSSION AND CONCLUSIONS}

The overall results on usability and user experience are very positive. The students think that the general design of our serious games is good. In particular, they think they are useful, relevant, fun, and easy to use. They express very positive emotions like pleasure, excitement, and joy and do not experience negative emotions like embarrassment, disappointment, sadness, disgust or anger. But a few of the student express a feeling of stress linked to the fear of not winning in the game or of making calculation errors. Thus, we can conclude that the design of our serious games does not cause usability problems.

In contrast to relatively scant prior evidence that learning mathematics with a serious game is better than a conventional approach (Mayer, 2014), the results of this study show a clear benefit to learning mathematics with a serious game. Students in the Experimental group learned significantly more, enjoyed their experience more, and made fewer errors than the students in the control group. If the control group was bored or unmotivated, this may have led them to make more errors and, in turn, enjoy their experience less.

Another important finding is that low prior knowledge students learned more about mental calculation from serious games than from using traditional method. In fact, the low prior knowledge students may be precisely the best targets for mathematics serious games. These students perform less well and seem to struggle more with mathematics, perhaps because they lack self-motivation or interest. Serious Games might get such students more excited and engaged in mathematics learning.

In terms of learning, the results presented here are encouraging. Indeed, our study shows that learning is better if we use serious games rather than in a traditional method. The justification for this result is linked in our opinion that the motivation and immersion made possible by serious games allow participants to more simply make the link between the elements with which they interact in the game and the reality of the activity which is simulated. Indeed, the paradigm of action learning supposes that by placing the learner in a situation where gestures and interaction are more realistic, the situated action will be better defined and the lived experience more conducive to learning.

\section{REFERENCES}

[1]. LOUBNA EL AZIZI, AZIZ ARBAI, “ Serious Games for the Development of Learning”.1st International Conference on "Affective computing, Machine Learning and Intelligent Systems” in Vol 5 No 4 (2017): Transactions on Machine Learning and Artificial Intelligence ISSN:2054-7390

[2]. LOUBNA EL AZIZI, "Development of Serious Games to Remedy the Problem of Innumeracy among Elementary School Students", International Journal of Science and Research (IJSR), https://www.ijsr.net/archive/v8i6/show_abstract.php?id=ART20199044, Volume 8 Issue 6, June 2019, $2072-2075$

[3]. LOUBNA EL AZIZI, " Design and Development of a Serious Mobile Game "MathAventure" ", International Journal of Advanced Research in Computer and Communication Engineering, Vol. 8, Issue 9, September 2019, DOI 10.17148/IJARCCE.2019.8903.

[4]. Information M.R.A. (2018) Gamification in Education: Breakthroughs in Research and Practice (Hershey, PA: IGI Global), pp. 1-677.

[5]. Laamarti F. and Eid M. and Saddik A.E. (2014) An Overview of Serious Games, (International Journal of Computer Games Technology), Volume 2014, Article ID 358152, 15 pages.

[6]. Ricciardi R. and Paolis L.T.D. and Saddik A.E. (2014) A Comprehensive Review of Serious Games in Health Professions, (International Journal of Computer Games

Technology), Volume 2014, Article ID 787968, 11 pages.

[7]. All A. and Castellar E.P.N. and Looy J.V. (2016) Assessing the effectiveness of digital game-based learning: Best practices, (Computers \& Education), vol. 92-93, pp. 90-103.

[8]. Petri G. and Wangenheim C.V.G. (2017) How games for computing education are evaluated? A systematic literature review, (Computers \& Education), vol. 107, pp. 68-90.

[9]. Barbosa A.F.S. and Pereira P.N.M. and Dias J.A.F.F. and Silva F.G.M.(2014) A New Methodology of Design and Development of Serious Games, (International Journal of Computer Games Technology), Volume 2014, Article ID n817167, 8 pages.

[10]. Baroody, A., \& Ginsburg, H. (1995). Children's mathematical learning: a cognitive view. In R. B. Davis, C. Maher, \& N. Noddings (Eds.), Constructivist views on teaching and learning of mathematics (pp. 51-64). Journal for Research in Mathematics Education Monograph Series, No. 4. Reston, VA: National Council of Teachers of Mathematics.

[11]. Wu B. and Wang A.I.(2012) A Guideline for Game Development-Based Learning: A Literature Review, (International Journal of Computer Games Technology), Volume 2012, Article ID 103710, 20 pages. 


\title{
International Journal of Advanced Research in Computer and Communication Engineering
}

\author{
Vol. 8, Issue 12, December 2019
}

[12]. Boyle E.A. and Hainey T. Connolly T.M. and Gray G. and Earp J. and Ott M. and Lim T. and Ninaus M. and Ribeiro C. and Pereira J. (2016) An update to the systematic literature review of empirical evidence of the impacts and outcomes of computer games and serious games (Computers \& Education), vol. 94, pp. 178-192.

[13]. Barab, S. A., Gresalfi, M., \& Ingram-Goble, A. (2010). Transformational play. Educational Researcher, 39(7), 525-536.

[14]. Brom, C., Sisler, V., \& Slavik, R. (2010). Implementing digital game-based learning in schools: augmented learning environment of 'Europe 2045'. Multimedia Systems, 16, 23-41.

[15]. D. Michael and S. Chen, Serious Games: Games That Educate, Train, and Inform, Course Technology PTR, 2005

[16]. Gee, J. P. (2009). Deep learning properties of good digital games: how far can they go? In U. Ritterfeld, M. Cody, \& P. Vorderer (Eds.), Serious games: Mechanisms and effects (pp.65-80) New York \& London: Routledge.

[17]. Hays, R. T. (2005). The effectiveness of instructional games: A literature review and discussion. Retrieved 10.05.06, from. http://adlcommunity.net/file.php/23/GrooveFiles/Instr_Game_Review_Tr_2005.pdf.

[18]. Hogle, J. G. (1996). Considering games as cognitive tools: In search of effective "Edutainment". Retrieved 12.01.05, from ERIC, ED 425737.

[19]. Kafai, Y. (1995). Minds in play: Computer game design as a context for children’s learning. Mahwah, NJ: Lawrence Erlbaum.

[20]. Keller, J.M., Suzuki, K. (2004). Learner motivation and E-learning design: a multi-nationally validated process. Journal of Educational Media, Vol. 29, No. 3, October 2004.

[21]. Ke, F. (2008a). A qualitative meta-analysis of computer games as learning tools. In R. E. Ferdig (Ed.), Handbook of research on effective electronic gaming in education (pp. 1-32). New York: IGI Global.

[22]. Ke, F. (2008b). Computer games application within alternative classroom goal structures: cognitive, metacognitive, and affective evaluation and interpretation. Educational Technology Research and Development, 56, 539-556.

[23]. Ke, F. (2008c). A case study of computer gaming for math: engaged learning from gameplay? Computers \& Education, 51(4), 1609-1620.

[24]. Marshall, M., \& Rossman, G.,B. (2006). Designing qualitative research. Thousands Oaks: Sage Publication. Miles, M., \& Hurberman, M. (1994). Qualitative data analysis: An expanded sourcebook. London: Beverley Hills.

[25]. Ritter, G.W., Barnett, J. H., Denny, G. S., \& Albin, G. R. (2009). The effectiveness of volunteering tutoring programs for elementary and middle school students: a meta-analysis. Review of Educational Research, 79(1), 3-38.

[26]. Baker, J. D., Rieg, S. A., \& Clendaniel, T. (2006). An investigation of an after school math tutoring program. Education, 127 (2), $287-293$.

[27]. Shaffer, D. W. (2005). Studio mathematics: The epistemology and practice of design pedagogy as a model for mathematics learning. Wisconsin Center for Education Research, Working paper, No. 2005-3.

[28]. Slavin, R. E., Lake, C., \& Groff, C. (2009). Effective programs in middle and high school mathematics: a best-evidence synthesis. Review of Educational Research, 79(2), 839-911.

[29]. Topping, K. J., Campbell, J., Douglas, W., \& Smith, A. J. (2003). Cross-age peer tutoring in mathematics with 7- and 11-year-olds: Influence on mathematical vocabulary, strategic dialogue and self-concept. Educational Research, 45(3), 287-308

[30]. Topping, K. J., Kearney, M., McGee, E., \& Pugh, J. (2004). Tutoring in mathematics: a generic method. Mentoring and Tutoring, 12(3), 353370.

[31]. Ashlock, R. B. (1987). Use of informal language when introducing concepts. Focus on Learning Problems in Mathematics, 9(3), 31-36.

[32]. Van Eck, R., \& Dempsey, J. (2002). The effect of competition and contextualized advisement on the transfer of mathematics skills in a computer-based instructional simulation game. Educational Technology Research and Development, 50(3), 23-41.

[33]. Vogel, J. F., Vogel, D. S., Cannon-Bowers, J., Bowers, C. A., Muse, K., \& Wright, M. (2006). Computer gaming and interactive simulations for learning: a meta-analysis. Journal of Educational Computing Research, 34(3), 229-243.

[34]. Julian ALVAREZ (2007) «Du Jeu vidéo au Serious Game : approches culturelle, pragmatique et formelle. » Thèse spécialité science de la communication et de l'information. Toulouse : Université de Toulouse II (Le Mirail), Université de Toulouse III (Paul Sabatier), décembre 2007, p.9.

[35]. Beck, J. C. (2004). Got Game: How the gamer generation is reshaping business forever. Boston: MA:Harvard Business School Press.

[36]. Aarseth, E. (2005). Game Studies: What is it Good For? The International Digital Media \& Arts Association Journal, No. Vol 1, no 3, pp. 3-7.

[37]. Bulander R. (2010) A conceptual Framework of serious games for higher education International Conference on e-Business, Athen, Greece, p 95-100.

[38]. Sonia Mandin (2010), Jeux sérieux : quels apprentissages ?, agence des usages des TICE, 2011.

[39]. Michel H., Kreziak D., Héraud., Evaluation de la performance des Serious Games, pour l'apprentissage : Analyse du transfert de comportement des éleveurs virtuels de Vacheland, Système d'Information Management, 2010

[40]. Bloom, S., Engelhart, M. D., Furst, E. J., Hill, W. H. \& Krathwohl, D. R.(1956), "Taxonomy of educational objectives: the classification of educational goals", Handbook I: Cognitive Domain New York, Longmans, Green, 1956.

[41]. Corti, K. (2006) Games-based Learning; a serious business application. PIXE Learning Limited.

[42]. Gee, J. P. (2003): What Video Games Have to Teach Us About Learning and Literacy, Palgrave Macmillan.

[43]. Karoulis A., et Demetriadis S. (2005). The motivational factor in educational games. Interaction between learner's internal and external representations in multimedia environments, Research report, Kaleidoscope NoE JEIRP, D21-02-01-F, 296-312.

[44]. Prensky, M. (2001) Digital Game-Based Learning. McGraw-Hill, Inc., New York, New York.

[45]. Kirreimur, J. (2004). Literature Review in Games and Learning. Nesta Futurelab Series, Report 8.

[46]. Prensky, M. (2001) Digital Game-Based Learning. McGraw-Hill, Inc., New York, New York. [16] Corti, K. (2006) Games-based Learning; a serious business application. PIXE Learning Limited. [17]Reix R. (2002), «Système d'information et management des organisations», Vuibert, 4ème édition, Paris. 